\title{
The Rehabilitation effects on the thermal behaviour of Algerian earthen built heritage.
}

\author{
Bencheikh Darda $^{1}$, Bederina Madani ${ }^{2}$. \\ ${ }^{1}$ University Saad Dahleb, ETAP laboratory, Architecture and urbanism institute, Blida, Algeria. \\ ${ }^{2}$ University Ammar Telidji, Civil engineering laboratory, Department of civil engineering, Laghouat, Algeria.
}

\begin{abstract}
The earthen built heritage presents today a state of deterioration due to the climate changes that put it seriously at risk, through the degradation of its envelope building materials. These degradations lead its occupants to rehabilitate it by using modern building materials. This paper focuses on the rehabilitation of vernacular earthen architecture and its influence on the thermal behaviour of ksourian houses in sub-arid zones. It is based on a comparative study that combines the site measurements and the numerical simulation by Energyplus. Two courtyard houses, constructed of an adobe brick, were evaluated, one in its initial shape and the other rehabilitated. The results shows that the rehabilitation of the envelope made on this house did not influence its thermal qualities significantly; a very small difference justified on its internal thermal behaviour was recorded in cold period and almost minor during summer.
\end{abstract}

\section{Introduction}

The sustainable approach reorients the foundations of architecture towards a greater consideration of the environment and the impact of any construction on nature [1], while ensuring comfort for the occupants and reducing their energy consumption, especially in the residential and tertiary set; an archetypal energyconsuming sector [2]. According to the National Agency for the Promotion and Rational Use of Energy (APARUE), its consumption in Algeria presents more than $40 \%$ of final energy consumption (2012), with an annual average of equal accommodation to 1,303 PET [3].

Indeed, the problem of energy consumption has been one of the major concerns for decades, particularly, in the hot and dry climate, due to the absence of thermal comfort, which obliged the residents to use active heating and air-conditioning systems, that account for $51 \%$ of the total energy consumed [4]. This problem has, in fact, favored the vernacular architecture, since these inhabitants have endeavored to treat the comfort passively, by the good adaptation of the primitive forms to the context in which it fits [5], without resorting to the usual modern technical installations. The use of a building material characterized by a high thermal inertia is one of the main rules that lead to the creation of thermal comfort in this architecture [6] (a result which was demonstrated in a study of the effect of the thermal inertia on the hygrothermal comfort under the sub-humid climate), and consequently to the reduction of energy consumption, according to a study made by Nayaran [7]. It should be underlined that this energy can be reduced to
$62 \%$ with an own selection of systems and building materials [8].

Among these materials, we can cite the rammed earth, a building material that all civilizations had adopted at one time or another. According to the United Nations, nearly $50 \%$ of the world's population lives in earthen houses [9]. It has been the most widely used building material in hot and dry climates [10], which has in fact endowed the vernacular architecture with a hygrothermal comfort without resorting to the active system, thanks to its inertia and its excessive thickness, which varies from 0.5 to 1 meter [11].

Traditionally, a regular maintenance of earthen houses was sufficient, but today most of these houses (34\% of the world's sites [12]) show a significant deterioration caused by the climate change, which have placed them seriously at risk, and have lead their inhabitants to ignore them, and sometimes to rehabilitate them. The studies of Kadri (2011), Sarbu (2011) and that of Sam (2012) have reported that the rehabilitation of stone and concrete structures improves the internal quality of the houses in terms of thermal comfort and reduces its energy consumption factor [13, 14, 15]. For that purpose, the present paper seeks to examine the impact of earthen vernacular building rehabilitation, especially adobe houses rehabilitation, on the thermal comfort (as criteria of built heritage assessment) under sub-arid climate, through evaluating two houses, one degraded and the other rehabilitated, by site measurements, in order to validate the results by numerical simulations.

This study may be an opportunity to highlight the thermal comfort aspect in the vernacular architecture or to make it reappear. 


\section{Material and methods}

The Temperature measurements were taken under winter and summer conditions (January and July, when temperature drops and peaks were predicted) by using a thermo-hygrometer with Self-contained mechanical recording. This instrument has enabled to measure the temperatures by a metal bimetallic strip (Accuracy: \pm $1 \%)$.

In order to validate the results recorded in site measurements, a numerical simulation using the Energyplus software (version 1.2.2) have been developed. Previously, a laboratory tests were conducted on a sample of an adobe. In fact, these tests permit to determine the characteristics required for the study (density, thermal conductivity and specific heat) to execute these simulations.

\section{Study case: vernacular ksar of Zgag El-Hadjadj}

The studied ksar is an example of vernacular architecture of southern Algeria. It is located in the region of Laghouat $\left(33.8^{\circ} \mathrm{N}, 2.9^{\circ} \mathrm{E}\right)$, which is characterized by a pre-Saharan climate (Figure 1), with a very hot summer, where temperatures can reach $40^{\circ} \mathrm{C}$, And a cold winter marked by a low temperature (which can decrease at $6{ }^{\circ} \mathrm{C}$ during the day and at $-2^{\circ} \mathrm{C}$ during the night) .

The Ksar of Zgag El-Hadjadj is a set of compact habitat built in height, developed over an area of three hectares, in arborescent frame. It comprises 135 houses spread over eleven islets of irregular pentagonal shape oriented North-South (Figure 2). Its urban fabric is structured by squares, streets, alleys and impasses [1617]. This organization enables to limit the effects of heat by minimizing the walls exposed to the sun, thus contributes to summer thermal comfort [18]. This ksar was classified as a national cultural heritage in 2007.

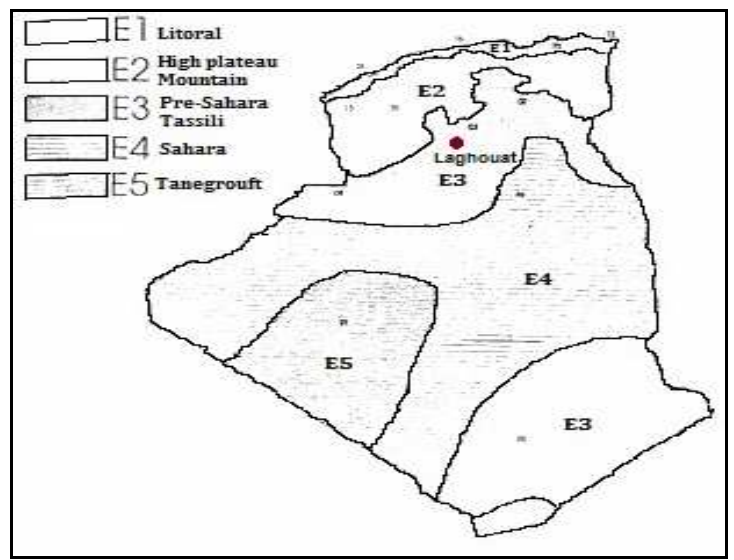

Fig. 1. Location of study region [19].

The Ksar's houses are developed on square plans; they are characterized by introversion and centrality. The construction system used is composed of adobe brick walls with stone basement (with an average thickness of 50 to $70 \mathrm{~cm}$ ) and palm's trunk or poplar's joist beams.

\subsection{Pathology and disorder}

The houses of Ksar Zgag El-Hadjadj are currently in a state of a very advanced degradation threatening the hygiene, comfort and safety of their inhabitants. The visit of the houses allowed to examine the visible disorders at the level of the structure and to identify all the potential sources of the deterioration observed. The pathologies encountered are inherent to the adobe's high vulnerability to erosion.

For the delivery of a few houses in habitation conditions, these disorders have been treated by tackling the causes of symptoms. The rehabilitation was carried out by several works, shown in the table below.

Table 1. Rehabilitation work made at rehabilitated houses.

\begin{tabular}{|c|l|}
\hline Problem & \multicolumn{1}{|c|}{ Solution } \\
\hline $\begin{array}{c}\text { Damaged } \\
\text { supports }\end{array}$ & $\begin{array}{l}\text { The functional replacement or the } \\
\text { reinforcement by intermediate posts } \\
\text { arranged across the beam to be } \\
\text { strengthened, in order to mask it by false } \\
\text { ceilings. }\end{array}$ \\
\hline cracks & $\begin{array}{l}\text { The resumption by the intercalation with } \\
\text { more resistant elements (pieces of brick), } \\
\text { and sometimes by the grouting with earth } \\
\text { to completely seal the vacuum. }\end{array}$ \\
\hline Unstuck & $\begin{array}{l}\text { The scratching and the repair using the } \\
\text { Sand-lime mixture, which promotes the } \\
\text { water vapour permeability required for } \\
\text { breathing the old masonry. }\end{array}$ \\
\hline Altered floor & $\begin{array}{l}\text { The Rebuilding with the stone floors, in } \\
\text { conder to be covered first with an insulated } \\
\text { concrete slab (while blocking the rising of } \\
\text { moisture). }\end{array}$ \\
\hline Rain run-offs & $\begin{array}{l}\text { The addition of gutters and gargoyles to } \\
\text { immobilize the water runoff. }\end{array}$ \\
\hline
\end{tabular}

\section{Results and discussion}

The investigation have been carried out on two houses (one in its initial shape and the other rehabilitated), which were carefully selected in order to evaluate the effect of rehabilitation on the thermal behaviour of earthen architecture. The study settled the parameter of centrality with regard to the ksar (Figure 2), which is common between both samples, and plays a key role in the thermal performance of the ksourian houses.

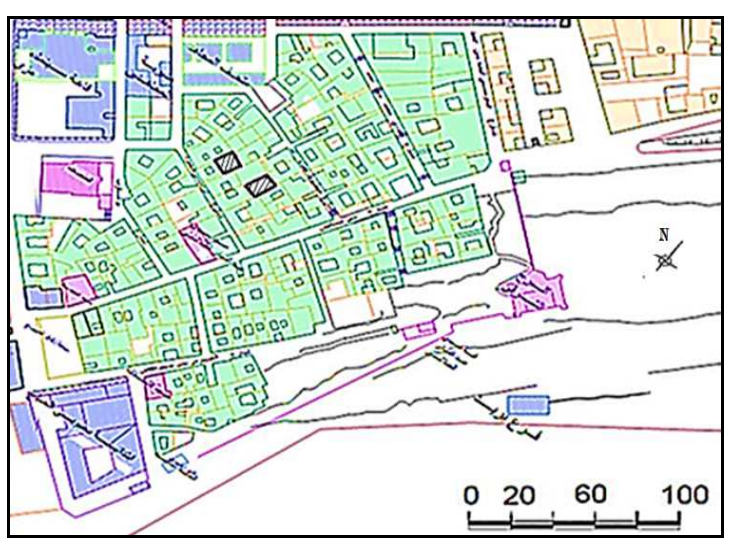

Fig. 2. Locations of study cases [16]. 


\subsection{Site measurements}

The temperature recordings were taken in the most exposed areas to hostile climatic conditions, which do not contain active heating and air-conditioning systems, as it has been seen above that the old inhabitants did not use it. For the rehabilitated case, the choice was mainly focused on the space where the rehabilitation affected the entire envelope. Rooms on the first floor with discontinuous occupancy have been selected (Figure 3-4), taking into account the parameters previously targeted. The courtyard is the chosen space control, to compare the results maintained inside the houses, since it presents the not covered space, which totally exposed to climatic conditions.

Note that the external hourly temperature recordings were obtained on the days of measurements (5-6 January and 9-10 July 2017), from the city meteorological station [20].

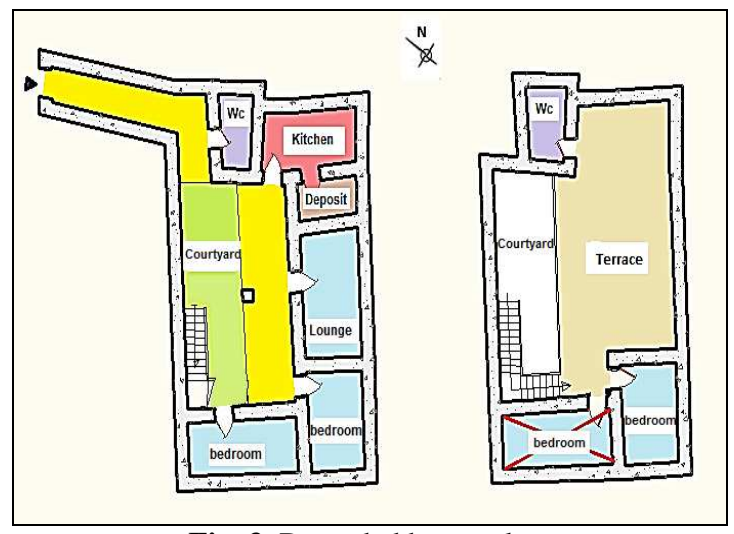

Fig. 3. Degraded house plan.

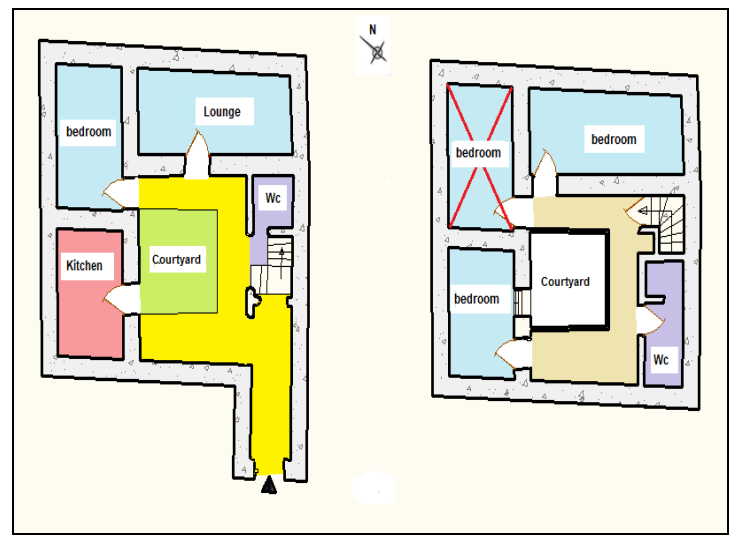

Fig. 4. Rehabilitated house plan.

\subsubsection{Degraded house}

The reading of the following graphs (Figure 5) shows that the internal temperature is stable throughout the day with an amplitude of $2.7^{\circ} \mathrm{C}$ between the maximum temperature $\left(9,9^{\circ} \mathrm{C}\right)$ marked about $5 \mathrm{pm}$ and the minimum one $\left(7,2^{\circ} \mathrm{C}\right)$ marked at $7 \mathrm{am}$. This stability is also remarkable in the courtyard, where the amplitude is equal to $2.33^{\circ} \mathrm{C}$, while outdoor temperatures have a high amplitude of $13^{\circ} \mathrm{C}$. This is translated by the amortization of the external contributions insured by the adobe [21], with delaying the cold transfers through the walls. This amortization had also a negative impact, which is obviously determined in the room temperature recordings, during the first eight hours, in which a more pleasant external environment was recorded, with a temperature difference that reached $6^{\circ} \mathrm{C}$. Indeed, the ventilation plays a major role in this phenomenon, by evacuating the cold air accumulated in the space during the night. This is clearly established from the results obtained in the courtyard, with an average temperature of $16.96^{\circ} \mathrm{C}$. The winter thermal comfort was not reached the inhabitants to use the fire placed in the bedroom, and the need of heating was only for no more than two months.

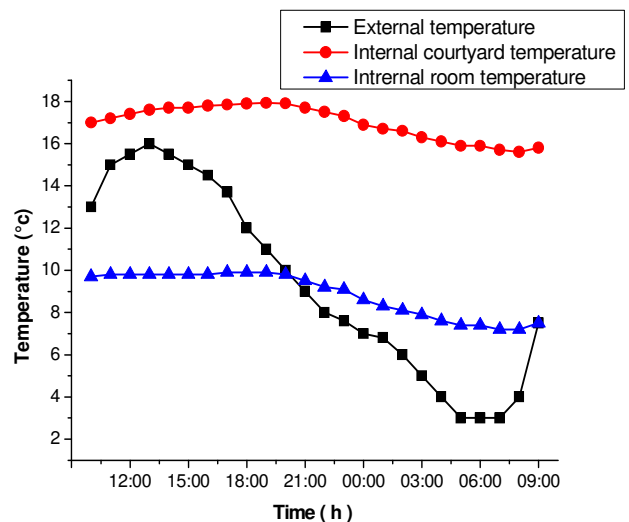

Fig. 5. Variation of winter temperature.

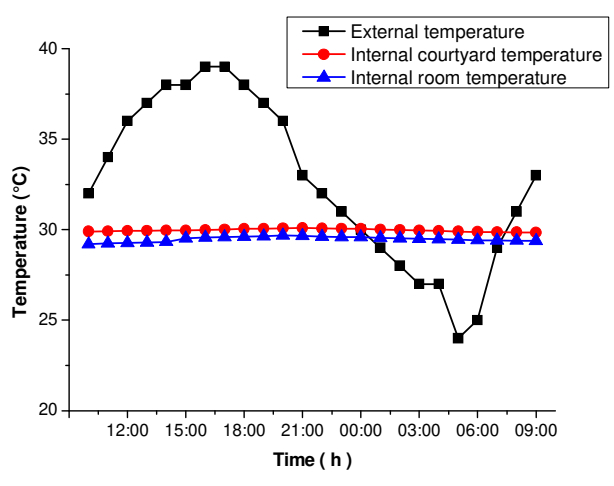

Fig. 6. Variation of summer temperature.

The range of thermal comfort is limited according to Givoni between 20 and $27^{\circ} \mathrm{C}$. For this purpose, it can be seen that thermal comfort is almost guaranteed in the warm period, inside the house (room and courtyard), where temperatures fluctuate slightly from 29 to $30.76^{\circ} \mathrm{C}$ in the shade. (Figure 6).The thermal inertia and the night ventilation are the recommended solutions, under the climatic conditions of July. The night ventilation was neglected by the inhabitants during measurements, which justify the summer results obtained.

\subsubsection{Rehabilitated house}

The results obtained from the graph presented below (Figure 7) shows that the winter interior temperature is almost constant (it varies between 7.5 and $11^{\circ} \mathrm{C}$ ), compared to the outside temperatures, where the amplitude is equal to $13^{\circ} \mathrm{C}$. This is justified by the thermal mass of the materials constituting the house envelope and the low ratio of openings in relation to the total area of the envelope, which limits the thermal losses. Nevertheless, these temperatures remain below the 
range of comfort determined by Givoni. However, at the courtyard, the temperatures recorded were approximately pleasant (with an average temperature of $13.29^{\circ} \mathrm{C}$ ) comparing it with those of the room; This is due to the direct solar contributions and the greenhouse effect provided by the nylon cover placed by the inhabitants during the cold period. On the other hand, its suppression during the warm period allows to ventilate the space naturally and consequently lowers the ambient temperatures, in order to stabilize it, thanks to the thickness of the wall (which is equal to $57 \mathrm{~cm}$ ) that permits to delay the transfer of heat received from a radiant heat source by storing it in the wall mass (Figure 8 ). Note that, compactness of the urban fabric limits the walls exposed to winds and solar radiations, which has further helped to achieve these results.

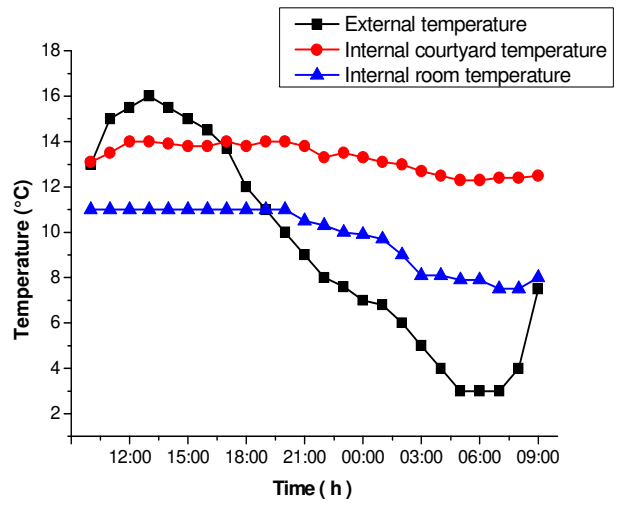

Fig. 7. Variation of winter temperature.

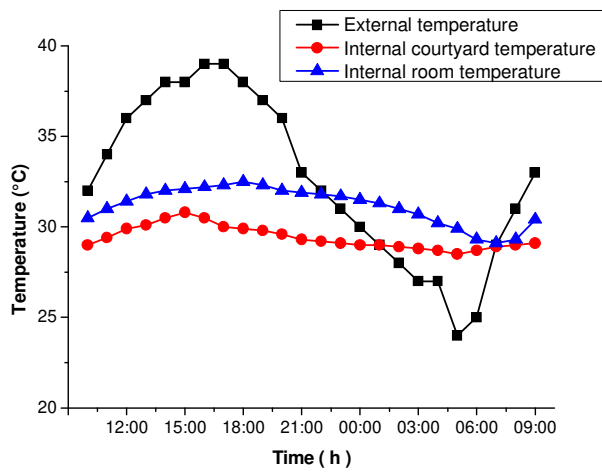

Fig. 8. Variation of summer temperature.

\subsubsection{Comparative analysis of thermal behaviour results}

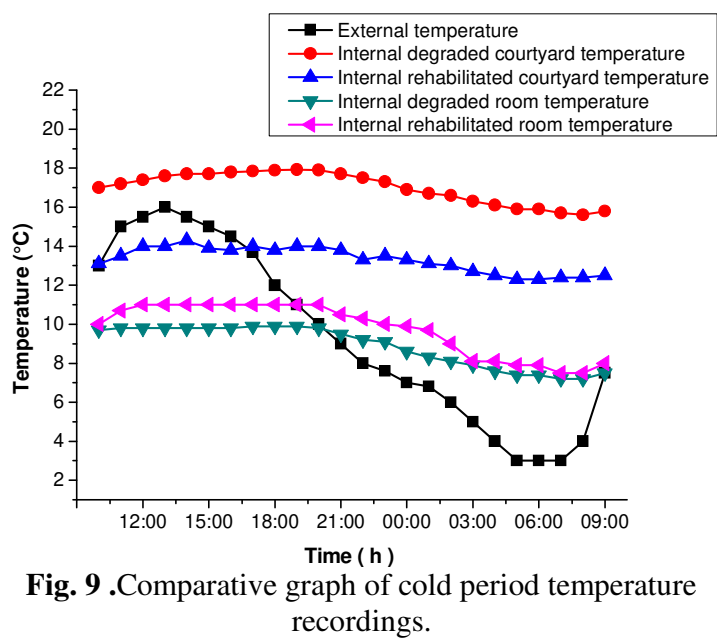

The site measurement results, shown graphically above (Figure 9), demonstrate that during the cold period, the courtyard thermal behaviour in the degraded house is more pleasant than that in the rehabilitated house, with an average difference of $3.67^{\circ} \mathrm{C}$. This is explained by the natural ventilation, which allows to release the cold air stoked in the walls during the night. On the other hand, the presence of nylon cover in the rehabilitated house courtyard slows down the evacuation of this air, which leads to its accumulation in space after its restitution. This coverage also has a positive impact on the thermal environment, which is summarized by the passive heating provided by the greenhouse effect. This is clearly established from the results, where an increase in temperatures was observed during the afternoon (direct solar radiation).

The resulting temperatures in the rooms have an average difference of $0.85^{\circ} \mathrm{C}$, which is reflected by the presence of a wall exposed to climatic conditions in the degraded case, the northeast orientation of this wall has negatively influenced the winter thermal comfort in the space.

The thermal inertia causes difficulties in terms of thermal regulation in intermittent occupancy spaces [22], which explains the low temperatures (out of comfort range) observed in the rooms of the two cases studied.

Figure 10 illustrates that the courtyards of the two houses show approximately the same results in the warm period. The small marked difference is justified by the surface, the shape and the location of the courtyard: the smaller and more centralized the courtyard, the more shadow is observed, the faster refreshment and a longlasting air pool puddle is marked [23].

Oppositely, a large difference of room temperatures between the two cases was recorded; this is expressed by the wall thickness, which varies from a house to another $(57 \mathrm{~cm}$ in the rehabilitated house and $65 \mathrm{~cm}$ in the degraded one). This thickness makes it possible to dampen the temperature variations resulting in the amplitude reductions [24]. The thicker the wall, the slower the heat transfers. These results are consistent with those obtained by other studies in the same field [25]. 


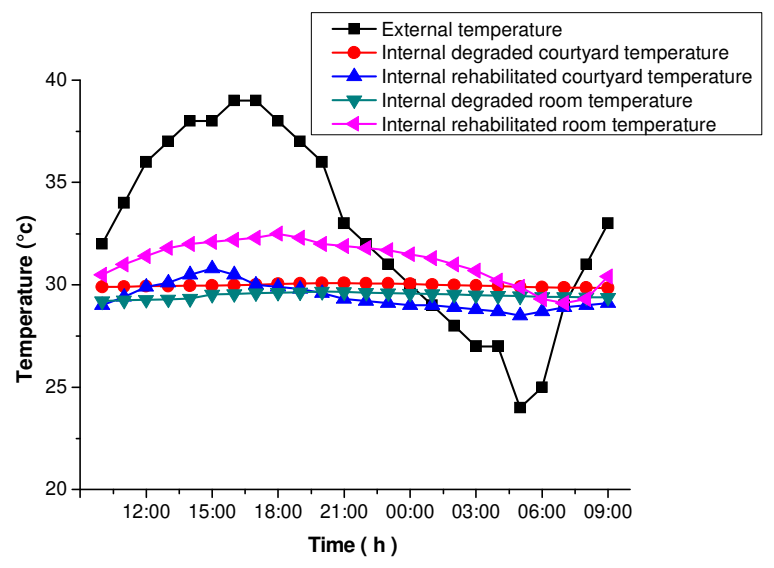

Fig. 10. Comparative graph of warm period temperature recordings.

From this comparison, it can be seen that the rehabilitation did not influence the house thermal qualities significantly; a very small difference justified on its internal thermal behaviour was recorded in cold period and almost minor during summer.

\subsection{Numerical simulations}

Energyplus is a software that has shown its performance and has been the subject of extensive validations [26]. The simulation by this software takes into account most of the parameters affecting the thermal balance, in particular the characteristics of the building materials; density, thermal conductivity, specific heat and thermal diffusivity, which have been determined, by taking an adobe sample results extracted from the ksar.

Table 2. Adobe characterization results.

\begin{tabular}{|c|c|}
\hline Characteristics & Values \\
\hline $\begin{array}{c}\text { Density } \\
\left(\mathrm{kg} / \mathrm{m}^{3}\right)\end{array}$ & 2567,6 \\
\hline $\begin{array}{c}\text { Thermal Conductivity } \\
(\mathrm{w} / \mathrm{m} . \mathrm{K})\end{array}$ & 0.817 \\
\hline $\begin{array}{c}\text { Specific heat } \\
\left(\mathrm{J} / \mathrm{kg} .{ }^{\circ} \mathrm{C}\right)\end{array}$ & 1075,1 \\
\hline $\begin{array}{c}\text { Thermal diffusivity } \\
\left(\mathrm{m}^{2} / \mathrm{s}\right)\end{array}$ & 0,7596 \\
\hline
\end{tabular}

The Ksar's organization was also taken into consideration during the simulation, in order to ensure the compactness of the urban fabric and the centrality of the studied houses in relation to their location. The architectural characteristics are often taken into account by this software in a simplified way, while guaranteeing a precision excellent level of houses behaviour.

The simulations are made without heating and air conditioning systems, using the meteorological data of the sub-arid climate of Laghouat.

Table 3. Site measurements /numerical simulations comparison (Degraded house).

\begin{tabular}{|c|c|c|c|c|}
\hline \multicolumn{2}{|c|}{} & \multicolumn{3}{|c|}{ Site measurements } \\
\cline { 3 - 5 } & Ext & courtyard & room \\
\hline \multirow{2}{*}{ Average } & $\begin{array}{c}\text { Cold } \\
\text { period }\end{array}$ & 9,57 & 16,96 & 8,86 \\
\hline
\end{tabular}

\begin{tabular}{|c|c|c|c|c|}
\hline $\begin{array}{c}\text { Temperature } \\
\left({ }^{\circ} \mathrm{C}\right)\end{array}$ & $\begin{array}{l}\text { Warm } \\
\text { Period }\end{array}$ & 32,71 & 29,96 & 29,46 \\
\hline & & \multicolumn{3}{|c|}{ Numerical Simulations } \\
\hline & & Ext & courtyard & room \\
\hline \multirow{2}{*}{$\begin{array}{c}\text { Average } \\
\text { Temperature } \\
\left({ }^{\circ} \mathrm{C}\right)\end{array}$} & $\begin{array}{c}\text { Cold } \\
\text { period }\end{array}$ & 11,81 & 15,36 & 9,83 \\
\hline & $\begin{array}{l}\text { Warm } \\
\text { Period }\end{array}$ & 34,43 & 29,37 & 29,25 \\
\hline
\end{tabular}

Table 4. Site measurements /numerical simulations comparison (Rehabilitated house).

\begin{tabular}{|c|c|c|c|c|}
\hline & \multicolumn{3}{|c|}{ Site measurements } \\
\hline & & Ext & courtyard & room \\
\hline \multirow{2}{*}{$\begin{array}{c}\text { Average } \\
\text { Temperature } \\
\left({ }^{\circ} \mathrm{C}\right)\end{array}$} & $\begin{array}{c}\text { Cold } \\
\text { period }\end{array}$ & 9,57 & 13,29 & 9,71 \\
\hline & $\begin{array}{l}\text { Warm } \\
\text { Period }\end{array}$ & 32,71 & 29,39 & 31,16 \\
\hline & & \multicolumn{3}{|c|}{ Numerical Simulations } \\
\hline & & Ext & courtyard & room \\
\hline \multirow{2}{*}{$\begin{array}{c}\text { Average } \\
\text { Temperature } \\
\left({ }^{\circ} \mathrm{C}\right)\end{array}$} & $\begin{array}{l}\text { Cold } \\
\text { period }\end{array}$ & 11,81 & 13,45 & 10,09 \\
\hline & $\begin{array}{l}\text { Warm } \\
\text { Period }\end{array}$ & 34,43 & 28,86 & 28,64 \\
\hline
\end{tabular}

The measurement/simulation comparison presented in the tables above shows a small average relative error of $1.07 \%$ between the measured and simulated data. This is reflected in the homogeneity of the building materials, which was assumed by the software. However, reality shows a significant state of aging. The uncertainty obtained can also be related to the positioning of the measuring instrument and its accuracy.

Lastly, in order to verify numerically the outcomes earlier revealed concerning the rehabilitation effects on the thermal behaviour, another simulation was made on the house before its rehabilitation; the results show a small average difference of $0.4^{\circ} \mathrm{C}$ in the room. On the other hand, no improvement had been made on the courtyard results, which is contrasted with the statement announced previously.

\section{Conclusion}

This work concretizes a comparative study relative to the thermal comfort, between two vernacular earthen houses, one in the initial shape and the other rehabilitated. The site measurements have made it possible to determine the thermal quality of the earthen built heritage during the cold and the warm season, and to check the influence of the envelope rehabilitation on its interior thermal behaviour.

The experimental results show that the summer thermal comfort of sub-arid zones can be assured by the thermal inertia of building materials and the natural ventilation; two complementary and indispensable parameters for effective results. 
It should be recalled, in this regard, that spatial organization of the old houses also favours their thermal behaviour; the courtyard centrality makes it possible to control sunshine by protecting from the summer sun, and also, to limit the overheating and lower the temperature by provoking a fresh air circulation, thus renewing the warm indoor air.

The comparison of the results obtained from two houses, showed that the rehabilitation of the envelope had a negligible effect on the thermal comfort. The reduction of the wall thickness and the presence of a wall exposed to climatic conditions were the parameters justifying the difference between the internal temperatures of the studied cases. This was also verified by a numerical simulation using the Energyplus software, which showed an average difference of $1.07 \%$. This concordance has as well permitted to affirm that this software adequately predicted the thermal comfort.

To summarize, it is important to emphasize that the vernacular earthen architecture refers to sustainable architecture; it is the object of a renewed interest, which must be exerted by a reinforced involvement of construction's actors. Its rehabilitation presents a symbolic act that demonstrates the cultural value of the goods to future generations.

\section{References}

1. A.Diemer, Développement durable plutôt qu'écodéveloppement : le nouveau gadget idéologique de l'occident. Colloque francophone; Les représentations Nord Sud du développement durable, Université Blaise Pascal - IUFM Auvergne (2012).

2. Transition to Sustainable Buildings. Strategies and Opportunities to 2050. IEA (2013). [ISBN : 978-9264-20241-2].

3. Ministère de l'Energie et des Mines, 'Consommation Energétique Finale de l'Algérie, Chiffre Clé -Année 2012-', in APRUE 'Données et Indicateurs'. Ed (2014).

4. G. Kang, D. Song. Optimized blind control method to minimize heating, cooling and lighting energy. Energy Procedia 78, pp.2857-2862 (2015).

5. C. Rubio-Bellido, P. Arcos, C. Lainez, M. José. Adaptation Strategies and Resilience to Climate Change of Historic Dwellings. Sustainability 7, pp.3695-3713, (2015).

6. D. Medjelakh, S.Abdou. Impact de l'inertie thermique sur le confort hygrothermique et la consommation énergétique du bâtiment. Revue des Energies Renouvelables 3 , pp. 329-341 (2008).

7. T. Narayan. A Passive Courtyard Home in Jaipur, India: Design Analysis for Thermal Comfort in a Hot Desert Climate. Arizona State University, [online] Thulasi.Narayan@asu.edu . Last saved 03/02/05.

8. B-V-V. Reddy, K-S. Jagadish, Embodied energy of common and alternative building materials and technologies .energy Build 35, pp129-37 (2003).

9. H. Guillaud. Architectures de terre Utilisée de tous temps et en tous lieux, la terre crue a de plus en plus d'adeptes dans le monde. Retour sur un matériau respectueux de l'environnement. Les matériaux de construction, TDC 977 (2009).

10. M. Gernot. Building with earth: Design and Technology of a Sustainable Architecture. Basel: Birkhäuser - Publishers for Architecture (2006).

11. K. Heathcote. The thermal performance of earth buildings. informes de la construccion; 62, 523 pp.117-126, (2016).

12. Word Heritage, inventory of earthen architecture. WHEAP (2012). [ ISBN: 978-2-906901-70-4]

13. N. Kadri, A. Mokhtari. Contribution à l'étude de réhabilitation thermique de l'enveloppe du bâtiment .Revue des Energies Renouvelables 14, 2 pp.301311, (2011).

14. F. Sam. Réhabilitation thermique d'un local dans une zone aride - Cas de Ghardaïa-. thèse de magistère, UMMTO (2012).

15. I. Sarbu, C. Sebarchievici, Thermal rehabilitation of building .International journal of energy 5, 2 (2011).

16. Plan permanent de sauvegarde et de mise en valeur du secteur sauvegardé ; Le vieux ksar de Laghouat $\mathrm{N}^{\circ} 11-141$ du 28 mars 2011/ JO N²0 du 30/03/2011.

17. A.N. Si Amer. La prise en compte des attributs touristiques dans le processus de patrimonialisation de l'espace oasien : cas de l'Oasis de Zgag El Hadjadj à Laghouat, Algérie. Colloque internationale ; Ressources patrimoniales et alternatives touristiques : entre oasis et montagnes, Ouarzazate, Maroc. Nov. 2011.

18. M. Khoukhi. N. Fezzioui. Thermal comfort design of traditional houses in hot dry region of Algeria». International Journal of Energy and Environmental Engineering (2012).

19. Ministère de l'habitat, Recommandations architecturales. Ed ENAG, Alger (1993).

20. R.O.M, Regional office of meteorology, Laghouat, (2017).

21. N. Matari, A .Mahi et M. Lachi, Effet de l'enveloppe du bâtiment sur le confort thermique. Application au climat aride. Congrès Français de Thermique SFT 2015, La thermique de l'habitat et de la ville, La Rochelle pp.1-8 (2015).

22. D. Pajani. La thermographie du bâtiment; principes et applications du diagnostic thermographique. Paris, Eyrolles, 216p, (2010).

23. P. Supic. L'aspect bioclimatique de l'habitat vernaculaire. Revue Architecture et Comportement. 10, pp.27-47 (1994).

24. P. Oliver. Built to meet needs; cultural issues in vernacular architecture. Oxford, Architectural press, 475p (2006)

25. S. Serrano, A. De Garcia, L-F. Cabeza. Adaptation of rammed earth to modern construction systems: comparative study of thermal behavior under summer conditions. Applied energy 175, pp.180-188 (2016).

26. C. Spitz. Analyse de la fiabilité des outils de simulation et des incertitudes de métrologie appliquée à l'efficacité énergétique des bâtiments. Thèse du doctorat, Université de Grenoble (2012). 